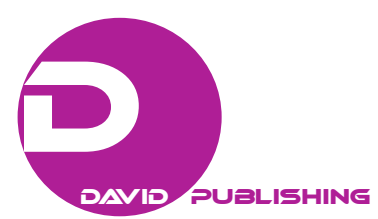

\title{
Comparison of Development of Housing Construction in Regions of Slovakia and Czech Republic
}

\author{
Zora Petráková, Martina Jurigová \\ Slovak University of Technology, Bratislava, Slovakia \\ Ján Dvorský \\ University of Žilina, Žilina, Slovakia
}

\begin{abstract}
Cities and municipalities are involved in the economic development of the whole country. One of the priorities of mayors is the usefulness of spatial disproportions of area as well as the structure and development of housing construction. They are natural canters of public and commercial services. The aim of the article is to determine if the geographic location of the region influences the number of new apartments with planning permission and completed apartments with a completion approval by using the methods of mathematical statistics "Analysis of variance". Meaning of the geographical location of the region as a factor, which influences the construction of apartments as well as regional differences in selected Central European countries, is subject of the conclusions of the paper.
\end{abstract}

Keywords: region, analysis of variance, planning permission, completion approval, development of housing, Kruskal-Wallis test

\section{Development of Housing in Slovakia and Czech Republic}

Now, it is possible to observe the increase of the population who has problem with providing private housing in houses or apartments, in the countries of Central Europe. Housing is one of the basic human needs that should be met at the level corresponding to the overall level of socio-economic development of society. The quality of housing and its availability are often perceived as evaluation indicators of living standards of society. In conditions of market economy, responsibility for finding their own housing is transferred to the citizens. The availability of housing is directly proportional to the economic possibilities of the individual (Petráková, 2015a; 2015b). Basic subjects, which have an impact on housing development by its scope, are the state, municipalities, higher territorial units, private sector, non-governmental sector, and the citizens themselves (O'keefe, 2012; Petráková, 2015a; 2015b). Development of housing in Slovakia is reflected to:

- citizen, who has the primary responsibility to obtain their own housing in a market economy. He is the main user of the housing stock;

- the private sector and non-governmental sector, for example, institutions of the financial market, investors,

Zora Petráková, Dr., Ing., Ph.D., Slovak University of Technology, Bratislava, Slovakia.

Martina Jurigová, Ing., Slovak University of Technology, Bratislava, Slovakia.

Ján Dvorský, Ing., Department of Crisis Management, Faculty of Security Engineering, University of Žilina, Žilina, Slovakia.

Correspondence concerning this article should be addressed to Zora Petráková, ÚSZ, Faculty of civil engineering STU, Radlinského 11, 81005 Bratislava, Slovakia. 
engineering and design organizations, construction companies, NGOs, and the population are involved mainly in the financing of housing development, land development and technical infrastructure, housing construction, management and renewal of housing stock, and providing other services related to housing;

- the scope of municipalities and higher territorial units, which are directed especially to the creation of spatial conditions for housing development within the territorial development of settlements. Under the current legislative framework, municipalities procure, among other things, concept of the development of individual areas of community life, co-operate in the formation of suitable living conditions in the village and provide, and approve programs of housing development of the village. The coordination and provision of land and technical facilities for the construction and the improving the management of public housing funds related to the above competencies of municipalities (Beck, Demirguc-Kunt, \& Levine, 2005);

- the scope of law, which is focused especially on the coordination of support measures from the state and improving support tools for housing development, as well as the transformation of the legislative framework under the market economy conditions. The role of the state, in addition to the legislative framework, is an earmarking adequate fund for the development of housing in the state budget (CFO, 2013).

\section{Development of Housing in Regions of Slovakia and Czech Republic in 2011-2014}

Government housing policy deals with relations between subjects and processes related to meeting the needs of housing (Habánik, Hošták, \& Kútik, 2013). Housing policy is also a combination of economic, social, legal, and technical context of housing, and it is directly related to the economic conditions of the country. The basic criterion for the housing policy success is to ensure long-term availability of housing for all social groups, because in the present phase of development of the society, only some are able to pay the cost of new construction of own resources (Mukwasi \& Seymour, 2012).

For comparison in construction and particularly in numbers of started and completed apartments between countries, regions with similar geographic, demographic, social, and economic conditions were selected. And they are neighbouring regions, which are divided by the only state border, which can be seen in Figure 1. Basic survey characteristics are the number of started apartments (apartments with a planning permission) and the number of completed apartments (apartments with a completion approval) to the region. These data in the monitored period 2011-2014 are shown in Table 1.

The development of the number of apartments with a completion approval in selected regions of Slovakia shows that the total number of completed apartments is 22,731 for the monitored period 2011-2014, and the average number of completed apartments is 1,894 per year and region. The development of the number of apartments with a completion approval in selected regions of the Czech Republic shows that the total number of completed apartments is 27,529 for the monitored period 2011-2014, and the average number of completed apartments is 2,294 per year and region.

Comparison of the development of the number of apartments with a completion approval between the regions of the Slovakia and Czech Republic shows that, in the region of Czech Republic, 400 more apartments are annually completed than in the region in the Slovak Republic for the period 2011-2014. Comparison of the number of dwellings with planning permission between regions in the countries shows that, in the region of the Czech Republic, an average of 350 more apartments are started to be built than that of the region in the Slovak Republic, for the period 2011-2014. The positive is that the differences in residential construction will be slowly reduced. 


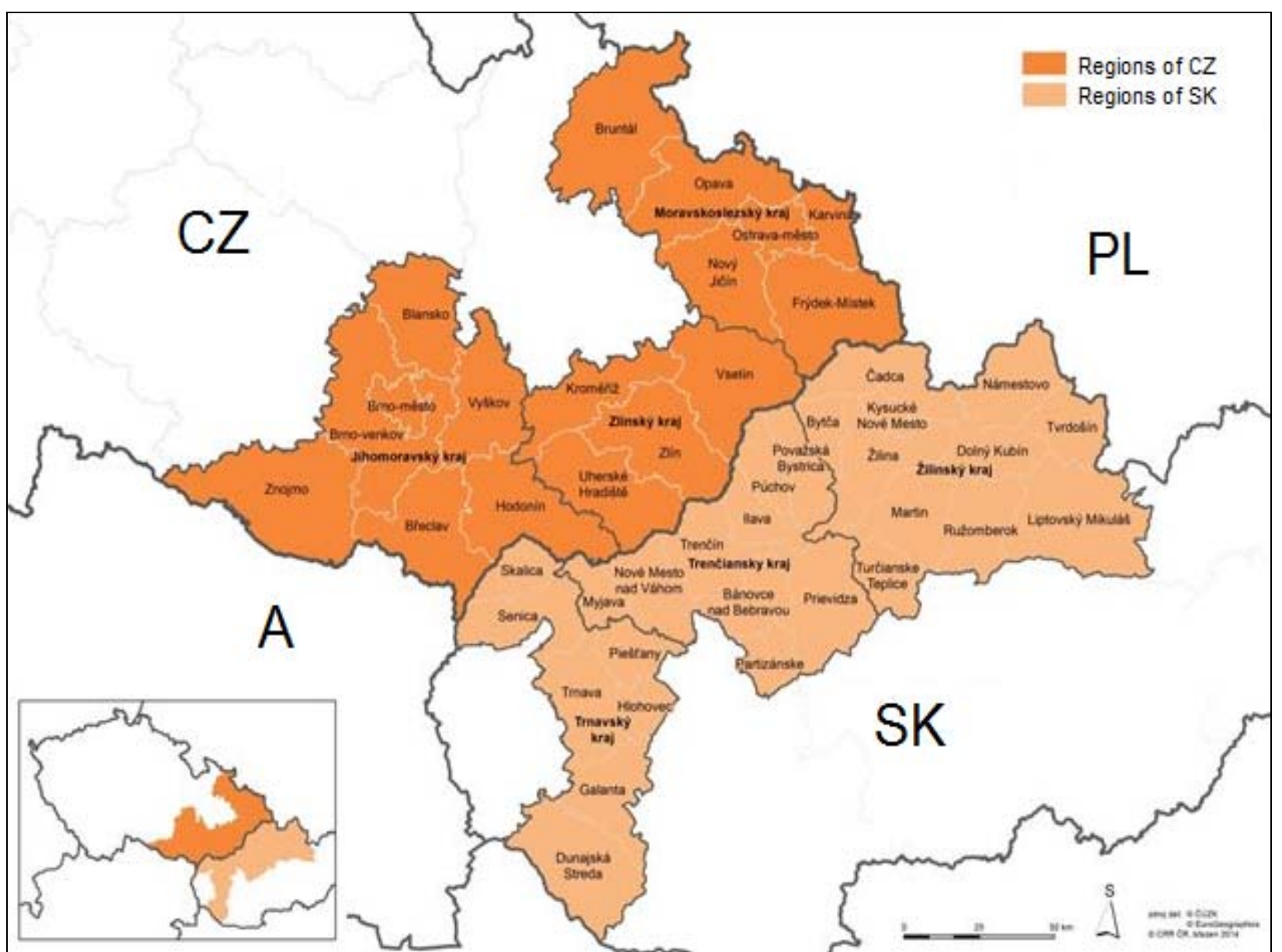

Figure 1. Geographical location of selected regions of Slovakia and Czech Republic. Source: Ministry of Regional Development of Czech Republic.

Table 1

Housing Construction in Selected Regions of Slovakia and Czech Republic

\begin{tabular}{llllllllllll}
\hline \multirow{2}{*}{$\begin{array}{l}\text { Selected regions of Slovakia } \\
\text { and Czech Republic }\end{array}$} & \multicolumn{8}{c}{ Monitored period 2011-2014 } \\
\cline { 2 - 13 } & \cline { 2 - 12 } & PP & CA & PP & CA & PP & CA & PP & CA & PP & CA \\
\hline \multirow{3}{*}{ SR } & Trnava & 1,890 & 2,614 & 1,887 & 2,403 & 2,204 & 2,334 & 2,452 & 2,334 & 8,433 & 9,685 \\
& Trenčín & 1,229 & 1,227 & 1,496 & 1,469 & 1,701 & 1,490 & 1,396 & 1,643 & 5,822 & 5,829 \\
& Žilina & 1,849 & 1,908 & 1,805 & 1,673 & 1,525 & 1,682 & 1,999 & 1,954 & 7,178 & 7,217 \\
\hline \multirow{3}{*}{ CZ } & South-Moravian & 3,380 & 3,608 & 3,008 & 3,770 & 2,807 & 3,516 & 3,650 & 3,242 & 12,845 & 14,136 \\
& Zlín & 1,128 & 1,090 & 1,145 & 1,137 & 854 & 792 & 941 & 806 & 4,068 & 3,825 \\
& Moravian-Silezian & 2,711 & 2,523 & 2,074 & 2,698 & 2,062 & 2,404 & 1,931 & 1,943 & 8,778 & 9,568 \\
\hline
\end{tabular}

Notes. PP-planning permission, CA-completion approval, SK-Slovakia, CZ-Czech Republic (Statistical Office of the Slovakia, 2016; Statistical Office of the Czech Republic, 2016).

Figure 2 shows that in the South Moravian Region, the highest average annual number of completed apartment is 3,534. In the Zlín Region, the average annual number of apartments is 957 . The ratio of number of completed apartments between these regions is 3.5. This fact is even more interesting that this is a neighbouring 
region in the Czech Republic. It may be explained by the geographic location of the South Moravian Region, which is attractive to young people, especially the proximity of the capitols of Austria and the Slovak Republic-Bratislava and Vienna. Other negative of the Zlín Region in the structure of housing construction is a linear downward trend in the number of started flats in the years of 2011-2014.

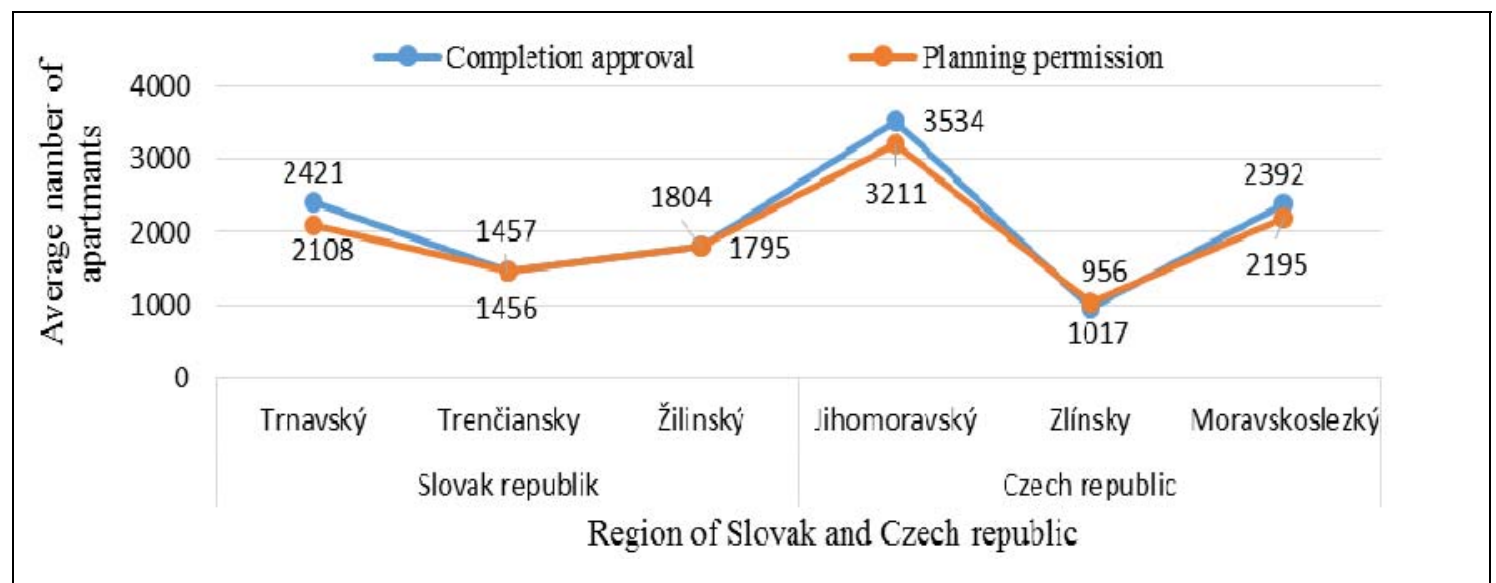

Figure 2. Development of the average number of planning permissions and completion approvals in selected regions of CZ and SK for the monitored period 2011-2014.

The number of apartments in selected regions of Slovakia, started, or completed, is steadily balanced slightly increasing linear trend in each region. On one hand, Trnava region has the highest number of apartments in selected regions. On the other hand, Trencin region, as the only region among the selected regions of Slovakia, has the highest annual increase of completed apartments each year.

\section{Comparison of Development of Housing Construction in Selected Regions of Slovakia and Czech Republic With Using of Mathematical Statistics Method "Analysis of Variance"}

By using statistical methods and tools, it was investigated that if the average (mean) number of apartments with a planning permission and with a completion approval in individual regions affects or does not affect the factor of geo-economic situation of the region. The quantitative method "analysis of variance" was used. For analysis of variance, parametric or non-parametric test was determined (Lajčin, Sláviková, \& Frankovský, 2015; Betáková, Lorko, \& Dvorský, 2014). In applying the method analysis of variance, analytics software STATGRAPHICS Centurion XVII was used, considering to the complexity of the numerical calculations of individual tests (Statgraphics Centurion XVII, 2016).

Table 2

\section{Basic Statistical Characteristics of Housing}

\begin{tabular}{|c|c|c|c|c|c|c|c|}
\hline \multirow{2}{*}{$\begin{array}{l}\text { Type of } \\
\text { apartment }\end{array}$} & \multirow[b]{2}{*}{ BSC } & \multicolumn{6}{|c|}{ Selected regions in Slovak and Czech Republic } \\
\hline & & $\begin{array}{l}\text { Trnava region } \\
\text { (TT) }\end{array}$ & $\begin{array}{l}\text { Trenčín region } \\
\text { (TN) }\end{array}$ & $\begin{array}{l}\text { Žilina region } \\
(\mathrm{ZA})\end{array}$ & $\begin{array}{l}\text { South Moravian } \\
\text { region }(\mathrm{B})\end{array}$ & $\begin{array}{l}\text { Zlín region } \\
(\mathrm{Z})\end{array}$ & $\begin{array}{l}\text { Moravian-Silezian } \\
\text { region }(\mathrm{T})\end{array}$ \\
\hline \multirow{2}{*}{ CA } & $\mu$ & 2421 & 1457 & 1804 & 3534 & 956 & 2392 \\
\hline & $\sigma^{2}$ & 133 & 172 & 148 & 221 & 182 & 322 \\
\hline \multirow{2}{*}{ PP } & $\mu$ & 2108 & 1456 & 1795 & 3211 & 1017 & 2195 \\
\hline & $\sigma^{2}$ & 273 & 197 & 198 & 377 & 143 & 350 \\
\hline
\end{tabular}

Notes. $\mathrm{PP}$ - planning permission, $\mathrm{CA}$-completion approval. 
For the calculation by parametric tests, two basic conditions had to be met- the resulting $p$-value of the homoscedasticity test (i.e. sameness of the variances of the apartments between monitored years) and from the test to verify the normality of groups of apartments according to its structure, it must be higher than chosen significance level 0.05. Data required for the analysis of variance are given in Table 2. These are the basic statistical characteristics of the number of apartments with the completion approval (BSC):

$\mu$ - the average number of apartments in the relevant region for the monitored period 2011-2014;

$\sigma$-the standard deviation number of apartments in the relevant region for the monitored period 2011-2014.

\section{Application of the Method “Analysis of Variance” Apartments With Completion Approval in Selected Regions in Slovakia and Czech Republic}

Investment companies and non-governmental sector can decide the time and the completion approval procedures for the residential buildings due to the sale and purchase capacity of the region and the attractiveness of the area. Development of the number of apartments with completion approval due to the geo-economic situation and the competitiveness of regions can affect the factor. For the use of parametric test of average numbers of apartments with a completion approval in the individual regions of the Slovak Republic, following conditions are met:

(1) Homoskedasticity was met. The resulting $p$-value by Cochran's test was 0.263 .

(2) Normality of the number of apartments with planning permission was met. In one group of companies, the $p$-value was less than a chosen significance level of 0.05 . Kolmogorov-Smirnov test found following values: $p$-value of TT region is $0.851 ; p$-value of TN region is 0.918 ; $p$-value of ZA region is $0.874 ; p$-value of B region is $0.991 ; p$-value of $Z$ region is $0.878 ; p$-value of $\mathrm{T}$ region is 0.941 .

Table 3

Analysis of the Multiplicity Variance of Flats With AD by Using Parametric F-test

\begin{tabular}{lllllc}
\hline Variance by CA & The sum of squares & Df & Mean squares & $F$-ratio & $p$-value \\
\hline Variance between regions of SR & $1.62 \mathrm{E} 7$ & 5 & $3.2427 \mathrm{E} 6$ & & \\
Variance in the regions of SR & 766,215 & 18 & $42,567.5$ & 76.18 & 0.0011 \\
Total variance & $1.6979 \mathrm{E} 7$ & 23 & & & \\
\hline
\end{tabular}

Table 3 shows that the resultant $p$-value from analysis of variance of the number of completed apartments by the $F$-test is 0.0011 . Value is less than a chosen significance level of 0.05 . It can be confirmed that there are statistically significant differences between the variance of multiplicity of apartments and CA in individual selected regions of Slovakia and Czech Republic at 95.0\% confidence level. The average values of the numbers of apartments with CA depend on the individual regions in Slovakia or Czech Republic.

The correctness of arguments is confirmed also by graphical analysis of the number of completed apartments in selected regions of SR and CZ by multipoint graph in Figure 3. The number of apartments with completion approval in Box-Whisker chart is in the scale of 1:1,000 apartments. It implies that the South Moravian Region has a significantly higher number of completed apartments with CA, followed by Trnava Region and Moravian-Silesian Region. 


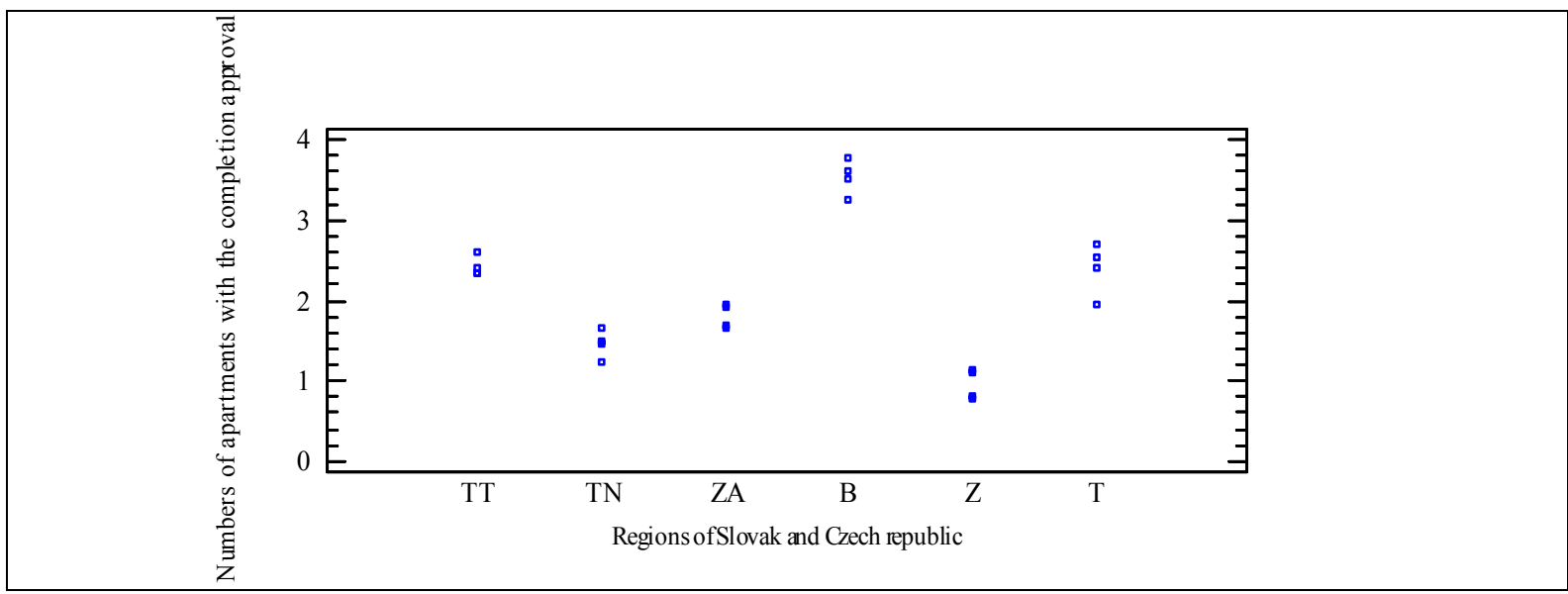

Figure 3. Comparison of regions with number of apartments with a completion approval using a scatter graph.

\section{Application of the Method “Analysis of Variance” of Apartments With Planning Permission in Selected Regions in Slovakia and Czech Republic}

For stable development in matters of housing structure and the strategy of its development, it is equally important to know the number of apartments with planning permission respectively, apartments which were started to be built. A comparison of the number of apartments which were started to be built, with the construction in selected regions of the Slovakia and Czech Republic, is the subject of the next section. For the use of parametric tests of average numbers of apartments with a completion approval in individual regions of Slovakia, the following conditions were not met:

(1) Homoskedasticity was met. The resultant $p$-value by using Cochran's test was 0.652 .

(2) Normality of the number of apartments with planning permission was not met. In one group of companies, the $p$-value was less than a chosen significance level of 0.05 . Kolmogorov-Smirnov test found following values: $p$-value of TT region is 0.044 ; $p$-value of TN region is 0.998 ; $p$-value of ZA region is 0.930 ; $p$-value of $\mathrm{B}$ region is $0.995 ; p$-value of $\mathrm{Z}$ region is $0.908 ; p$-value of $\mathrm{T}$ region is 0.595 .

Non-parametric two-choice Kruskal-Wallis test of median number of apartments with planning permission by selected regions of Slovakia and Czech Republic was subsequently made.

The results of non-parametric Kruskal-Wallis test of the method "Analysis of variance" shown in table 4 show that the calculated $p$-value of the number of apartments with planning permission is less than 0.05 . Based on these results, it can be said that there are statistically significant differences between the median frequency of apartments and completion approval in different regions of SR and $\mathrm{CZ}$ at $95.0 \%$ confidence level.

Table 4

Analysis of Variance of Numbers of Apartments With PP Using Kruskal-Wallis Test

\begin{tabular}{|c|c|c|c|c|c|c|}
\hline \multirow[b]{2}{*}{ Kruskal-Wallis test } & \multicolumn{6}{|c|}{ Selected regions in Slovak and Czech republic } \\
\hline & $\begin{array}{l}\text { Trnava region } \\
\text { (TT) }\end{array}$ & $\begin{array}{l}\text { Trenčín region } \\
\text { (TN) }\end{array}$ & $\begin{array}{l}\text { Žilina region } \\
\text { (ZA) }\end{array}$ & $\begin{array}{l}\text { South Moravian } \\
\text { region (B) }\end{array}$ & Zlín region $(\mathrm{Z})$ & $\begin{array}{l}\text { Moravian-Silezi } \\
\text { an region }(\mathrm{T})\end{array}$ \\
\hline Numbers of groups & 4 & 4 & 4 & 4 & 4 & 4 \\
\hline $\begin{array}{l}\text { The median number of } \\
\text { apartments with PP }\end{array}$ & 15.5 & 6.75 & 11 & 22.5 & 2.5 & 16.75 \\
\hline$p$-value & 0.0008 & & & & & \\
\hline
\end{tabular}


The correctness of the arguments is also confirmed by graphical analysis of the number of completed apartments in selected regions of Slovakia and Czech Republic by using the graph of deviations from the mean frequency of apartments with PP in Figure 4. It implies that the variation of the number of buildings in regions CZ PP is significantly higher than the variation from the number of apartments in the regions of PP SK in the years 2011-2014.

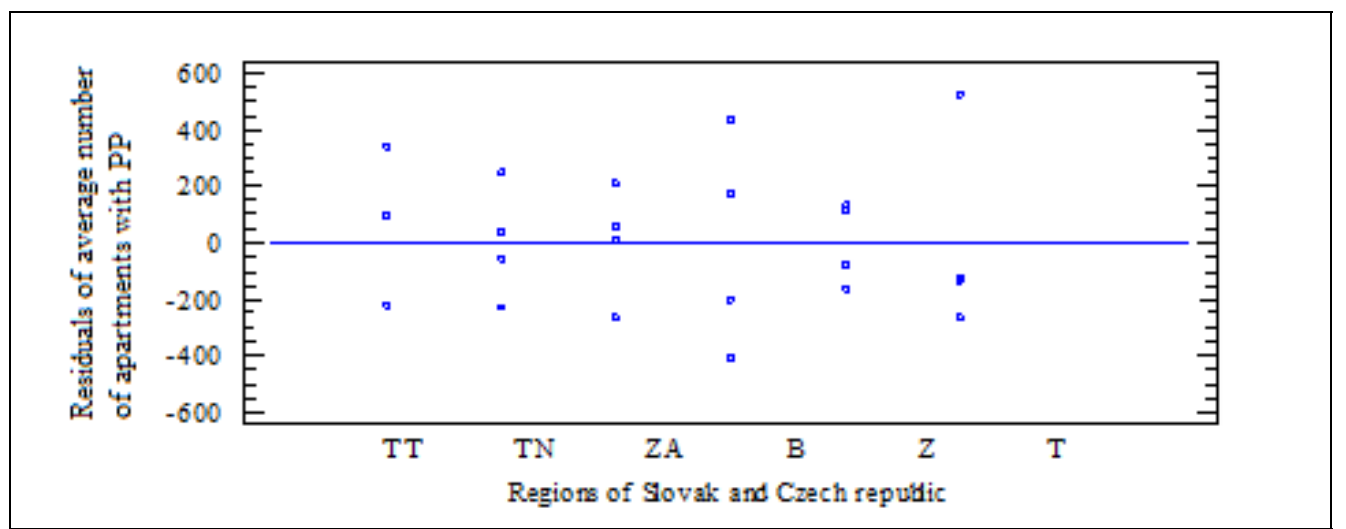

Figure 4. Comparison of deviations from the mean number of apartments with PP in selected regions of SR and CZ.

\section{Conclusion}

The results of comparison of the number of apartments between regions of the Czech Republic and Slovakia using the methods of mathematical statistics "Analysis of variance" make it clear that the differences between selected regions are significant. The differences between the Slovak and the Czech Republic are among the more than quarter of a century, since the split of the common state, is notable not only in economic, demographic, and cultural spheres, but also in terms of construction. This fact is boosted also in the construction and impacts are particularly felt by people living in east regions of Europe. They feel in the quality of housing, life, employment, as well as other social aspects. It can be seen that the differences in construction, started, or completed apartments are between countries, mainly variance of their annual frequency. Given the calculated basic statistical characteristics such as standard deviation, in the regions of Slovakia, the construction is more consistent than in the regions of the Czech Republic. One of the aims of the program INNTEREG V-A between $\mathrm{CZ}$ and SR is the continuity and development of the regions in the construction in the number of completed apartments and gradually reducing the differences in construction between regions. This is not possible without communication at all levels of government and public administration, along with investors and non-governmental sector, especially in terms of financing. To improve the facts and suggestion of preventive measures in the field of housing construction in cities and villages, an extension of competence is necessary despite the lack of funds for their performance, because at present it remains that funding from the European structural and investment funds are the primary means for financing the development of towns and villages, not only in the Slovak Republic, but also in the Czech Republic.

\section{References}

Beck, T., Demirguc-Kunt, A., \& Levine, R. (2005). SMEs, growth, and poverty: Cross-country evidence. Journal of Economic Growth, 10(3), 199-229.

Betáková, J., Lorko, M., \& Dvorský, J. (2014). The impact of the potential risks of the implementation of instruments for environmental area management on the development of urban settlement. Environmental Impact II, Ancona, 91-101. 
Controlling and Financial Organization (CFO). (2016). Risk management: The most important risks for the European Companies. Retrieved from http:/www.cfo.sk/articles/risk-manazment-najvacsie-rizika-ktorym-celia-europske-firmy\#.UjbZIMZM-Qo Habánik, J., Hošták, P., \& Kútik, J. (2013). Economic and social disparity development within regional development of the Slovak Republic. Economics and Management, 18(3), 457-464.

Lajčin, D., Sláviková, G., \& Frankovský, M. (2015). Social intelligence as a significant predictor of managerial behaviour. Economics Journal, 6, 646-660.

Mukwasi, C. M., \& Seymour, L. F. (2012). Enterprise resource planning business case considerations: A review for small and medium-sized enterprises. Journal of Innovation Management in Small \& Medium Enterprises, 1-15.

O'keefe, S. (2012). The impact of slow growth policies on local economies: Through housing boom and bust. Routledge Journals, Taylor \& Francis LTD, 30, 66-72.

Petráková, Z. (2015a). Projektovýmanažment-Nástroj pre prípravu a riadenie. Eurostav, spol. s. r. o. Bratislava, 21(1-2), 44-45. Petráková, Z. (2015b). Posudzovanie nákladov stavebných projektov. Eurostav, spol. s. r. o. Bratislava, 21 , 66-67.

STATGRAPHICS: Statgraphics Centurion XVII. (2016). Retrieved from http://www.statgraphics.com/ Statistical Office of the Czech Republic ŠÚ ČR. (2016). Retrieved from https://www.czso.cz/csu/czso/bvz_cr Statistical Office of the Slovakia. (2016). Retrieved from http://slovak.statistics.sk/ 